\title{
Water Nakba in Palestine: \\ Sustainable Development Goal 6 versus Israeli hydro-hegemony
}

Zayneb al-Shalalfeh ${ }^{\mathrm{i}}$, Fiona Napier ${ }^{\mathrm{ii}}$ and Eurig Scandrett ${ }^{\mathrm{iii}}$

${ }^{\mathrm{i}}$ School of International Development, University of East Anglia, Norwich

${ }^{\text {ii }}$ Independent environmental scientist, Aberdeen

iii Public Sociology Research Group, Queen Margaret University, Edinburgh 


\section{Abstract}

This Viewpoint article argues that Sustainable Development Goal 6, which aims to ensure the availability and sustainable management of water and sanitation for all, cannot be achieved for the Palestinian people under the current political situation of Israeli occupation. Through the practice of hydro-hegemony, Israel controls all water resources in Israel and the Occupied Palestinian Territory, thus denying water sovereignty to the Palestinians. This is demonstrated through three case studies: The Jordan Valley; the West Bank settlements; and Gaza. The politics of water in Israel and the Occupied Palestinian Territory is best understood as part of the dynamics of settler colonialism, in which ethnic cleansing is achieved through the dispossession of essential resources. The authors discuss what role the international scientific community can play in supporting Palestinian water sovereignty and therefore SDG 6.

\section{Keywords}

Water, Sustainable Development Goals, Israel, Palestine 
"The economic life of Palestine depends on the available water supply. It is, therefore, of vital importance not only to secure all water resources already feeding the country, but also to be able to conserve and control them at their sources"

Chaim Weizmann, Zionist Organisation, address to Paris Peace Conference 1919

\section{Introduction}

Sustainable Development Goal (SDG) 6, launched in 2015, aims to ensure the availability and sustainable management of water and sanitation for all. The lack of access to water for Palestinians has been well documented. In this paper, we do not present new data but rather draw on existing published sources as well as recent field observations in Palestine (Israel and the Occupied Palestinian Territory (OPT)) as professionals in water and environmental science and solidarity activists. We argue that the achievement of SDG 6 for Palestinians requires a political solution in which the international scientific community and civil society must take responsibility.

Sustainable water management in any river catchment or aquifer requires sovereignty over those resources, or equitable sharing if they are transboundary. In Palestine, Israel has total control over all transboundary resources. The lack of Palestinian sovereignty over their equitable share of water means a condition of permanent water insecurity with impacts on domestic consumption, human health, agriculture and food sovereignty. The case studies in this paper illustrate the impossibility of Palestinians implementing sustainable water management without political steps towards water sovereignty. 
Whilst there have been initiatives for seeking to address the problems of water management, they have all been unable to tackle water security issues because they are based on models of cooperation between Israel and the OPT which reproduce what Zeitoun (2012) has called Israeli hydro-hegemony. Cooperation between the Palestinian Authority and Israel, in which the latter have complete sovereignty of water, is a mechanism for the implementation of Palestinian compliance with Israel's water demands.

It is clearly in Israel's interests to sustain hydro-hegemony as an efficient means of retaining control of water resources for its own citizens. However, the denial of water sovereignty to Palestinians can be understood in the context of settler colonialism (Veracini 2006, 2010, 2015). Settler colonialism occurs where a settler population colonises land through systematically expelling the indigenous population. Water politics in Palestine is a continuation of the organised expulsions of 1947-8 known as al-Nakba - the 'catastrophe' (Pappe 2006, Marsalha 2012).

Whilst the crisis of water insecurity is well documented, the following case studies serve to illustrate the impacts of Israeli hydro-hegemony and the lack of Palestinian water sovereignty.

\section{Jordan River}

The Jordan is a 360-kilometre long river that flows roughly north to south from Lebanon and

Syria through the Sea of Galilee to the Dead Sea on the border of OPT and the Hashemite Kingdom of Jordan.

Since the nineteenth century wave of European Jewish colonisation (the Aliyah), the Jordan River was subject to many projects which aimed to impose Zionist control (Isaac and Shuvel 
1994, Isaac \& Hilal 2011, Zeitoun 2012). In 1875, British military Engineer General Sir Charles Warren advocated irrigating the Negev for accommodating five million Jewish immigrants.

Under the British Mandate there were several studies of the Jordan valley's water resources and in 1944 Lowdermilk published Palestine Land of Promise in which he recommended:

- completing investment in agriculture in Jordan river area in order to secure farms and industry for 4 million Jewish immigrants, using the river water for generating electricity;

- diverting the water from the River Jordan to the Negev desert;

- transmitting water from the Mediterranean to the Jordan valley for generating electricity and maintaining the water level in the dead sea.

This project, as the Jordan Valley Authority, became the Zionist/Israeli policy for unilateral exploitation of the Jordan. In 1946, the Hayes project established a 10 year plan to transform the Lowdermilk project into reality regardless of the laws governing transboundary water rights, and this was implemented, despite protests from neighbouring countries, following the establishment of Israel in 1948.

In 1955, the Johnston plan proposed allocating water from the Jordan River on the basis of the right to an equitable and reasonable share between the riparian populations, including 250 million $\mathrm{m}^{3}$ per year for the Palestinians of the West Bank. The plan was obstructed by Israel and never ratified. Instead, Israel unilaterally constructed the National Water Carrier to divert the River Jordan from the Lake of Galilee to the Negev.

Finally, with the 1967 occupation of the remainder of Palestine, Israel established physical control of the entire water source of the Jordan catchment: all tributaries of the upper Jordan basin, Golan valleys and a significant part of the Yarmouk River. In the 1967 Six-Day War and 
shortly afterwards, Israel destroyed or confiscated all 140 pumping stations on the east and west banks of the Jordan River. Since then Israel has established the 'Eastern Militarised Zone' along the Jordan valley and denied Palestinians in the West Bank physical access to the riverbanks and water resources. At the same time Israel pumps 600 million $\mathrm{m}^{3}$ annually from the Jordan for use in Israel and the settlements.

By the 1970s Israel was physically controlling almost all available sources of fresh water from the Jordan River and its catchment (including the Golan Heights annexed from Syria) as well as the underground aquifer water. With the Oslo accords of the 1990s, physical control then shifted to hegemonic control, in which the implementation of Israeli control was delegated to the Palestinian Water Authority under Israeli supervision (Zeitoun 2012). At the same time, Israel signed Wadi Araba treaty with Jordan in 1994 in which the two parties mutually recognized the rightful allocations of the Jordan River. Despite the fact that over $90 \%$ of the Jordan Basin falls within the borders of neighbouring Arab countries, Israel currently abstracts around $58.3 \%$ of its water in violation of the riparians' rights, leaving Jordan, Syria, Lebanon, and Palestine with 25.76\%, 12.12\%, 0.38\%, and 0 respectively (Isaac \& Hilal 2011; Palestine Hydrology Group, 2010).

In the last 50 years, the River Jordan's annual flow has dropped from more than 1.3 billion cubic meters per year to less than 30 million cubic meters. It is, ironically, the sewage that is keeping the river alive today. Israeli practices have resulted in major ecological consequences for the Jordan River eco-system and for the Dead Sea, the level of which has been dropping by over one metre per year due to the combined impact of water diversions and the Israeli and Jordanian mineral extraction industries. 
In May 2013, the Israel Water Authority allowed $9 \mathrm{mcm} /$ year of fresh water to flow regularly from the Sea of Galilee into the Lower Jordan River, a concession celebrated by joint Palestinian, Israeli and Jordanian environmental NGO Eco-peace Middle East. Eco-peace have come under significant pressure from Palestinian environmentalists and expelled from Friends of the Earth International for colluding in and 'normalising' the occupation, and consequently muting criticism of the cause of the ecological disaster - Israeli hydro-hegemony.

In 2012, the World Bank issued a report on a feasibility study for the Red Sea - Dead Sea canal project, to transfer 2 billion cubic meters of water and construct a hydro-powered desalination facility near the Dead Sea. It would annually provide Jordan with $560 \mathrm{mcm}$ of desalinated sea water by 2060 and allow a swap of $60 \mathrm{mcm}$ of water between Jordan and Israel which will save the latter transmission costs. Additionally, it aims to restore the Dead Sea for Israeli and Jordanian tourism. The feasibility study raised concerns about the environmentally feasibility (Coyne Et Bellier, 2012). In 2013, the occupied Palestinian Authority signed a memorandum of understanding with the Israelis on the margin of this project for buying additional $32 \mathrm{mcm}$ of water (Reuters, 2017).This inset the Palestinians as a party in the project, although, there is no reference to their interest (MAS, 2013). In December 2016, the first phase of the project was initiated under an agreement in which Israel will receive the most benefit without being responsible for its operation (Namrouqa, 2016).

The ecological problem with the River Jordan is in the first place political, since Israel uses most of the river water in violation of the transboundary rights of its neighbouring Arab states and totally depriving the Palestinians. 


\section{The settlements}

Israel's occupation of the West Bank and Gaza Strip in June 1967 (known as al-Naqsa 'setback'), resulted in a second major displacement of Palestinians. Additionally, it put the West Bank and Gaza strip under a military occupation that controls all natural resources.

Directly after the war Israel issued military order 92 which gave 'the absolute authority of controlling all issues related to water to the Water Officer who is appointed by the Israeli courts.' In November of the same year, military order 158 put all water sources and projects under the full command of the Israeli Military Commander and required Palestinians to obtain a permit for any water project (Messerschmid, 2011).

Shortly after the war, Israeli Labor Minister Yigal Allon presented an unofficial plan to Prime Minister Levi Eshko, which proposed controlling the Jordan River and considering it the Eastern border of Israel. Additionally, it suggested annexing areas in the Jerusalem corridor and dividing the West Bank to northern (Nablus, Jenin, Tulkarm and Ramallah), southern (Hebron and Bethlehem) and eastern (Jericho and a crossing to Jordan) enclaves (Allon, 1967). This plan became the basis for Israeli settlements in the West Bank and the same year, the first settlement was built (Human Rights Watch, 2010).

Settlements violate Article 49 of the Geneva Convention of 1949, which declares that 'the Occupying Power shall not deport or transfer parts of its own civilian population into the territory it occupies' (ICRC, 1949). United Nations Security Council resolution 446 stated "that the policy and practices of Israel in establishing settlements in the Palestinian and other Arab territories occupied since 1967 have no legal validity and constitute a serious obstruction to achieving a comprehensive, just and lasting peace in the Middle East" (United Nations Security 
Council, 1979). This resolution has not prevented Israel from continuing its settlements expansion activity.

In 1981, the Israeli cabinet adopted 'Drobless plan' for increasing the number of Israeli settlers in the West Bank. The size of settlements has considerably increased, some with financial support from the Settlement Department of the World Zionist Organization which receives its budget from the Israeli government (Human Rights Watch, 2010).

In 1993 and 1995, the Oslo Accords were agreed which divided the West bank into three administrative parts: cities (A), towns (B) and rural land (C) to be transferred gradually to the Palestinian authority except for the issues in the permanent status negotiations - including water and settlements. Thus, Oslo legitimized Israeli control of the West Bank land and water (Ayoub, 2003).

The peace process has not reduced general settlement activity, nor did the Gaza disengagement plan of 2005. Before signing Oslo in 1993, there were 255,172 settlers (Ayoub, 2003). In 2012, the settler population was estimated at 547,000 (B'Tselem, 2015) in about 150 settlements in the West Bank; in addition to some 100 "outposts" erected by settlers without official authorization (OCHA, 2012). The Israeli government provides significant financial benefits and incentives, discounts on utilities and transportation, loans, agricultural land and huge supply of water for agricultural and domestic consumption (MA'AN, 2012).

The World Health Organization recommends a minimum daily domestic consumption of 100 litres per person: Israelis consume 300 litres; settlers 369 litres; compared to 73 litres for West Bank Palestinians (Koek, 2013). Settlers receive nearly as much water as the whole West Bank population approaching 3 million (PCBS 2016). The settlements and associated industrial 
activity are using and contaminating Palestinian water. In addition, some settlements plant waterintensive products for exporting, and virtually export Palestinian water by doing so.

Many of the settlements in the Jordan valley have an internal supply system. Most of the settlements though are supplied by the Israeli national water company Mekorot, which controls and operates wells inside Israel in addition to 42 wells in the West Bank (Koppelman and alShalalfeh, 2012). More importantly, it controls transboundary water of the region and supplies the Israelis and Israeli settlers at the expense of the Palestinians and other Arab neighbours. Mekorot was established in 1937 by Histadrut (Zionist Labour Federation), the Jewish Agency for the Land of Israel, and the Jewish National Fund (Davis, 2012) to serve the Zionist colonisation project and has always supported settlement activity.

Settlements provide obvious examples of water discrimination for their Palestinian neighbour communities. For example, Megilot Regional Council allocated in 2011 for 21 settlements in the Jordan valley a total of 21,475 litres/ person/ day for domestic and agricultural use (ARIJ, 2013). On the other hand, some of the neighbouring Palestinian communities such as al-Hadidya, alFarsiya, and Ras al-Akhmar are prevented access to the water network, and buy water from tankers at a cost several times the price of the tap water, and their average daily consumption per person is only 20 litres (Hareuveni, 2011). Settlements today control 42.8\% of the West Bank land between built-up area and land reserves (Ayoub, 2003) and give justification to sustain the military occupation of the area. It is shredding the West Bank into tiny pieces which kills the potential for a viable Palestinian state.

Israeli policy and settler violence are together using water control to ethnically cleanse area C from Palestinians. Palestinians are only allowed to build on $0.5 \%$ of area $\mathrm{C}$ including construction or rehabilitation of WASH structures (El-Ad, 2016). In the years 2010 and 2014, 
only $1.5 \%$ of building permit applications were approved by the Israeli Civil Administration (OCHA, 2015). Settlers attack Palestinians and prevent access to their land and water. In 2011, the United Nations reported a total of 56 springs, $93 \%$ of which are in area C: settlers had taken over 30 of these with 26 at risk of settler confiscation, while their Palestinian owners have been prevented access mostly by 'acts of intimidation' (OCHA, 2012). The occupation leaves agriculture and animal husbandry as the only option for many Palestinians in area $\mathrm{C}$ and then restricts their access to water and land. The impact extends beyond area $\mathrm{C}$ to the whole West Bank. For instance, almost one quarter of the communities connected to the water network receives less than 50 liters per person per day (Koppelman and al-Shalalfeh, 2012).

Despite this, the water situation in the occupied Palestinian territory is usually addressed as a shortage. Distribution of water tankers, drilling cisterns and establishing filling points are typical water projects which many foreign governmental and non-governmental organizations repeatedly implement, but which maintain the status quo by providing temporary, insufficient and inefficient solutions (Messerchmid, 2013). In addition, they are expensive where a big part of the infrastructure and service cost remain the responsibility of the individual citizen. Many Palestinians pay extra to use a household pump, for mobile tankers and for roof tanks and cisterns. Availability and cost of water affects domestic water management and thus consumes women's and girls' time.

\section{Gaza}

Gaza is in extreme water crisis. Latest estimates suggest only 5\% of water from the Strip's single source of fresh water - the Coastal Aquifer - is fit for human consumption, being heavily contaminated by infiltration of raw sewage from cesspits and sewage collection ponds, from 
brackish and seawater (Amnesty International, 2009). The UN warns that if nothing changes, the aquifer will be beyond recovery by 2020 (MEMO, 2015). The 2014 conflict alone inflicted an estimated $\$ 33$ million of damages to water infrastructure and losses of $\$ 94$ million to the entire water sector, and up to 90 litres of untreated or partially treated wastewater are being discharged into the Mediterranean every day (OCHA, 2016), contaminating Gaza's beaches and fishing waters. Moreover, Gaza's current catastrophic condition is a direct result of Israel's military occupation and blockade. Gaza does not lack the technical expertise to ensure the sustainable management of its resources, or the treatment of its wastewater; what it lacks is the freedom to do so.

The Gaza Strip is one of the most densely populated regions on the planet -1.8 million people living in a strip of land 25 miles long by an average 5 miles wide. The Coastal Aquifer is shared with Israel. Its annual sustainable yield is around $450 \mathrm{mcm} / \mathrm{y}$ in Israel, but only $55 \mathrm{mcm} / \mathrm{y}$ in Gaza - far short of the population's needs. Historically, Wadi Gaza (a stream originating in the West Bank) used to flow through Gaza to the coast, providing an additional water resource. However, the vast majority of flow from this stream is now diverted into a dam in Israel, and no longer reaches Gaza (Amnesty International, 2009).

Moreover, this lack of access to fresh water is exacerbated by erosion of sanitation capacity. OCHA (2016) recently reported;

In recent years, the longstanding shortage of adequate sanitation infrastructure in the Gaza Strip has resulted in the discharge of around 90 million litres of untreated or partially treated sewage into the sea every day, posing serious health and environmental hazards. Development of water and sanitation infrastructure has been severely impacted by the import restrictions imposed by Israel in its nine-year blockade of the Gaza Strip. 
At present, as many as 23 WASH items such as pumps, drilling equipment and disinfectant chemicals are on the Israeli "dual use" list, meaning that entry of such items to Gaza is severely restricted.

These import restrictions prevent development and routine maintenance, but make repairing the extensive damage to infrastructure caused during the frequent Israeli bombing campaigns (most recently in 2014) next to impossible. As reported by the United Nations Conference on Trade and Development (UNCATD) in 2015;

'Large scale investment in water, electricity and sanitation infrastructure was needed even before the damage inflicted by the military operation in 2014. The operation resulted in severe damage on Gaza's water and sanitation infrastructure, including water wells and networks, tanks, desalination units, wastewater networks and pump stations. The preliminary static value of the damage is estimated by the Palestinian Water Authority at more than $\$ 34$ million. However, long-term repair of the accumulated damage and decay of the water and sanitation infrastructure will require \$620 million.' (UNCTAD, 2015)

Despite Israel's assertions that the 2005 withdrawal of all settlers from Gaza meant Gaza was no longer subject to Israeli occupation, the UN still considers Gaza as part of the OPT. Article 42 of the Hague Regulations states clearly, 'Territory is considered occupied when it is actually placed under the authority of the hostile army'. (Avalon Project nd). The existing blockade, militarily enforced since 2007, grants Israel full authority and control over Gaza's borders, waters and airspace. 
The same Israeli Military Orders apply to water resources throughout the OPT, effectively placing all water and land related issues and constructions under the control of the Israeli army. The Oslo II Accords of 1995 granted Israel control over the majority of shared water resources, including the Coastal Aquifer. As part of that agreement, Israel agreed to sell 10 million m3 of water to Gaza each year, but in reality only ever provided half that volume. The 10 million $\mathrm{m} 3$ target was finally met in 2015 , but given that Oslo was only ever intended to be an interim arrangement, this volume is now completely inadequate to deal with the needs of Gaza's increased population twenty years later (McDermott \& Gould, 2016). Israel also forbids any transfer of water from the Mountain Aquifer in the West Bank to Gaza (Amnesty International, 2009).

Amnesty International (2009) reported 95\% of Gaza municipal well water as unsuitable for human consumption. With no other source available, Gaza is over pumping from the aquifer, which puts the water level below sea level. However, it is not the sea water that primarily contaminates the aquifer, it is brackish flow from over pumping in the Israeli side of the coastal aquifer.

The harsh restrictions of the blockade, and the repeated campaigns of mass bombing (often specifically targeting water and sanitation infrastructure) have resulted in a drastic state of social and environmental deterioration. Although the siege has a major effect on aquifer water quality, the main problem is denying access to Gaza's equitable share of water. If nothing changes, the UN prediction that Gaza may be uninhabitable by 2020 seems an increasingly likely outcome. 


\section{Conclusion}

Water access and consumption in Palestine is not sustainable. These case studies demonstrate that water supply is not what makes the region unsustainable, but rather control of water - water sovereignty. Such situations require political solutions.

Israel is in almost total control of Palestinian access to this life source, and is exploiting that control for the purposes of repressing and excluding the Palestinian population. Despite the development of technologies in water conservation and management in the agricultural field, Israel domestic consumption is higher than the UK, and Israel's geopolitical practices are overconsuming water from all its sources throughout the region. Israel continuously breaches international agreements, UN resolutions and international law in relation to access to water. Even if Israel were to abide by its own agreements and international obligations, just and sustainable access to water would not be possible.

Israel's systemic dehydration of the Palestinian people can only be explained in terms of settler colonialism. The lethal dispossession of essential resources from an indigenous population has been a tool used by settler colonial societies in the past for the purposes of ethnic cleansing.

Achieving SDG6 in Palestine requires, as a first step, for Israel to fulfil its obligations under international laws and agreements to which it is a signatory. But 'transboundary' agreements cannot be a solution whilst control of water and other environmental resources is used as a settler colonial tool of ethnic cleansing. Equitable sharing in international law is meaningless in a situation where there are no equal partners to share. Water sovereignty for the Palestinian people in Gaza, the West Bank and Israel, can only fully be achieved by dismantling of the colonial relationship between the Israelis and the Palestinians - ie by a regime of equality. For that to occur, Palestinians have sought help from international civil society, including the academic 
community, through a campaign of boycott, divestment and sanctions against the Israeli state and companies that profit from the situation (BDSmovement, 2017). The demands of this campaign are Israeli adherence to international law as it affects the Palestinians in the OPT, in Israel and the diaspora.

Israel enjoys complete physical and hegemonic control over Palestinian water resources and is using this power to deny Palestinian water sovereignty for the purposes of ethnic cleansing and settler colonisation of the entire land and resources of Palestine. The implementation of SG6 is impossible under these conditions. The contribution that the international academic community can make to achieving SDG6 in Palestine is a political one, to help to equalise the power relationship between Israel and the Palestinians by supporting the campaign to boycott, divest from and sanction Israel. 


\section{References}

Al-Sheikh, B., 2011. 'Occupied Palestinian Territories' in E.A. Radford, G. Catullo and B. de Montmollin (eds) Important Plant Areas in the south and east Mediterranean region: Priority sites for conservation. Gland, Switzerland and Málaga, Spain: IUCN pp 44-47.

Allon, Y., 1967. 'Israel: The Case for Defensible Borders', Foreign Affairs. Available from: https://www.foreignaffairs.com/articles/israel/1976-10-01/israel-case-defensible-borders. [accessed: 14 January 2017]

Amnesty International, 2009 Troubled Waters-Palestinians denied fair access to water.

Available from: http://www.amnestyusa.org/pdf/mde150272009en.pdf [accessed 23/07/17]

Applied Research Institute - Jerusalem ARIJ., 2013 Trading your Neighbours Water. Ramallah: Rosa Luxemburg Stiftung.

Avalon Project 2017 'Hague Convention IV' in Documents in Law, History and Diplomacy Lilian Goldman Law Library; Yale Law School. Available from: http://avalon.law.yale.edu/20th_century/hague04.asp\#art42 [accessed 26 July 2017]

Ayoub, H., 2003 Oslo accords and a new strategy for the Israeli settlements expansion in the occupied territories (1993 - 2003) Ramallah: National Bureau to Defend the Land and Resist Colonial Settlements - Palestinian Liberation Organization.

BDSmovement 2017 Boycott, Divestment, Sanctions. Available from: https://bdsmovement.net/ [accessed 27 July 2017]

B’Tselem, 2015 Statistics on Settlements and Settler Population, Available from: http://www.btselem.org/settlements/statistics. [Accessed: 14 January 2017].

Davis, U., 2012 The Jewish National Fund and Palestinian Water Rights Ramallah: LifeSource. 
El-Ad, H., 2016. Speech about settlements at the United Nations Security Council Available from: http://www.btselem.org/settlements/20161014_security_council_address. [Accessed: 07 November 2016].

Et Bellier, C., 2012. Red Sea - Dead Sea Water Conveyance Study Program Feasibility Study: Draft Final Feasibility Study Report - Summary Report. New York: The World Bank.

Hareuveni, E., 2011. Dispossession and Exploitation: Israel's Policy in the Jordan Valley and Northern Dead Sea. Jerusalem: The Israeli Information Center for Human Rights in the Occupied Territories B'Tselem.

Heller, J. 2017. 'Trump envoy announces Israeli-Palestinian water deal, silent on peace prospects', Reuters. Available from http://www.reuters.com/article/us-israel-palestinians-usawater-idUSKBN19Y1EZ [accessed 26 July 2017]

Human Rights Watch, 2010. Separate and Unequal: Israel's Discriminatory Treatment of Palestinians in the Occupied Palestinian Territory. United States of America: Human Rights Watch.

ICRC, 1949 Geneva Conventions of 1949 and Additional Protocols, and their Commentaries. International Committee of the Red Cross. Available from https://ihldatabases.icrc.org/applic/ihl/ihl.nsf/vwTreaties1949.xsp [accessed 27 July 2017]

Inbar, M., 2002 A Geomorphic and Environmental Evaluation of the Hula Drainage Project, Israel Australian Geographical Studies • July 2002 • 40(2):155-166

Isaac, J. and H. Shuval, J. 1994 (Eds) Water and Peace in the Middle East. Amsterdam: Elsevier

Isaac, J. and Hilal, J. 2011 'Palestinian landscape and the Israeli - Palestinian conflict', International Journal of Environmental Studies, 68:4, 413-429 
Kaplan, D. \& Kadmon, A. 1999 Ecodiversity Changes in the Hula Valley, Israel During this Century. Pultusk: LIFE Third Countries

Koek, E. 2013 Water for one people only. Occupied Palestinian Territory: al-Haq, P 52.

Koppelman, S. and al-Shalalfeh, Z., 2012 Our right to water: the human right to water in Palestine. Ottawa: Council of Canadians.

Maan Development Center. 2012 Parallel realities: Israeli settlements and Palestinian Communities in the Jordan Valley. Occupied Palestinian Territory: Maan Development Center.

MAS. 2013 Final Report, Round Table Discussion (3) The Red Sea-Dead Sea Water Conveyer: The Project, the Assessments and Potential Benefits to the Palestinian Territory. 26 March. Ramallah: Palestine Economic Policy Research Institute

Masalha, N., 2012 The Palestine Nakba: Decolonising History, Narrating the Subaltern, Reclaiming Memory. London: Zed books

McDermott, J, Gould, K., 2016 'How to Solve Gaza’s Water Crisis’ Time Magazine Available from:

http://time.com/4301139/gaza-water-crisis/ [accessed 23 July 2017]

Messerchmid, C., 2013 Back to the Basics: Policy Options for Palestinian Water Sector Development. Ramallah: Rosa Luxemburg.

Middle East Monitor, 2017 'Pollution blights 50\% of Gaza's beaches'. Available from: https://www.middleeastmonitor.com/20150902-un-gaza-could-be-uninhabitable-by-2020/ [accessed 23 July 2017] 
Namrouqa, H. 2016 'Donors pledge around \$400 million for Red-Dead project', The Jordan Times, 03 December. Available from: www.jordantimes.com/news/local/donors-pledge-around400-million-red-dead-project' [accessed 26 July 2017]

Office for the Coordination of Humanitarian Affairs OCHA., 2012 The humanitarian impact of Israeli policies. Jerusalem: OCHA.

Office for the Coordination of Humanitarian Affairs OCHA., 2012 How Dispossession Happens: the humanitarian impact of the takeover of the Palestinian water springs by Israeli settlers. Jerusalem: OCHA.

Office for the Coordination of Humanitarian Affairs OCHA., 2015 Under threat: demolition orders in area $C$ of the West bank; Jerusalem: OCHA.

Office for the Coordination of Humanitarian Affairs OCHA, 2016 'Gaza: shortage of sanitation infrastructure raises health and environmental concerns'. Available online at https://www.ochaopt.org/content/gaza-shortage-sanitation-infrastructure-raises-health-andenvironmental-concerns [accessed 23/07/17]

Palestinian Hydrology Group, 2010. Water Resources. Available from: http://www.phg.org/fast_facts.asp. [Accessed: 23 July 2017]

Pappe, I., 2006. The Ethnic Cleansing of Palestine. Oxford: One World

United Nations Conference on Trade and Development (UNCTAD), 2015. Report on UNCTAD assistance to the Palestinian people: Developments in the economy of the Occupied Palestinian Territory. Available from: http://unctad.org/meetings/en/SessionalDocuments/tdb62d3_en.pdf [accessed 23/07/17]

United Nations Security Council, 1979. Resolution 446 (22 March 1979), available from: https://documents-dds-ny.un.org/doc/RESOLUTION/GEN/NR0/370/60/IMG/NR037060.pdf?OpenElement 
Veracini L., 2006. Israel and Settler Society. London: Pluto Press

Veracini, L., 2015. The Settler Colonial Present. Basingstoke: Palgrave Macmillan

Veracini, L., 2010. Settler Colonialism: a Theoretical Overview. Basingstoke: Palgrave Macmillan

Zeitoun, M., 2012. Power and Water in the Middle East. London: I.B.Tauris 